\title{
MYTHOPOETICS OF HALYNA PAHUTIAK'S SHORT PROSE
}

\section{Bokshan H. I.}

\section{INTRODUCTION}

Novels and novelettes dominate among Halyna Pahutiak's literary works. The most popular works of this writer are the novels "The Servant from Dobromyl", "Urizh Gothic", the collection of novelettes "The Notes of the White Bird", "The Heavenly Dressmaker" and others. The author confessed in her interview: "I am really more inclined to write big compositions $<\ldots>$. It is explained by the fact that it is more difficult to write one original story than a novel" ${ }^{1}$. Even her first book contains not short prose but novelettes "The Children", "The Novelette about Maria and Magdalena", "Lialechka and Matsko" and the novel "The Philosopher's Stone".

H. Pahutiak's short prose is represented by stories and novellas and sometimes it is not easy to differentiate between them. For instance, in the selected works "The Sunset in Urizh" such compositions as "You will be Burnt by the Sun" and "The Mystery of the Heaven" are characterized by a detailed narrative manner combined with unexpected and intense plots, which are inherent to novellas. The cycle "Seven Novels" corresponds to the rules of the genre manifesting such attributes of a novella as "laconism, economy of portraying and expressing means" ${ }^{2}$.

H. Pahutiak's literary works are characterized by aesthetics of the irrational, fantasy, intuitive and dreamlike, therefore she is strongly influenced by gothic literature. But it is necessary to stress that traditional attributes of gothic prose deserted old houses, blighted areas with forests or bushwood - in H. Pahutiak's prose always acquire the features of psychoanalytical symbols and semantics of archetypes.

Concentration of mythopoetic characteristics in H. Pahutiak's novellas and short stories is as high as mythological intertexts are distinct in her novelettes and novels.

\section{Biblical intertexts in the writer's short prose}

Mythocentric character of $\mathrm{H}$. Pahutiak's fiction manifests itself in the titles of her short stories which indicate the vector of literary analysis, making researchers use archaic codes to interpret them. For instance, in the story "Once the Tower of Babel..." allusive relationship with the Book of Genesis

\footnotetext{
${ }^{1}$ Хвіртка в сад Галини Пагутяк: інтерв'ю з Г. Вдовиченко. URL: http://archieve/wz/lviv/ua/ articles/pg/249_(дата звернення: 11.07.2014).

2 Літературознавча енциклопедія: у 2 т. Київ : ВЦ «Академія», 2007. Т. 1. С. 128.
} 
highlights the motif of apostasy of people who decided to reach the sky being arrogant and pretentious. In the author's essay "The Tower being Built from the Top" the biblical motif acquires new arrangement through the correlation with the semantics of the binary opposition "top-bottom": "Kant started building his Tower from the top, not from the bottom, and it did not fall down like the Tower of Babel" ${ }^{3}$. Therefore, the inability of ordinary people to build the tower in this way is considered by H. Pahutiak as their incapacity to understand harmony of the Universe, reflected in the sky (the top).

In the novella "The Numbers of the Alive and the Dead" the author actualizes the mythosemantics of numbers. At the beginning the narrator speaks about five children, who were "like five fingers on one's hand" 4 . Since this number "means human microcosm, completeness of human existence" ${ }^{5}$ in mythology, a regressive movement from five to one can reflect gradual destruction of microcosm. After the eldest son's death in the war four children were left: "For each corner. A child for each corner" 6 . H. Pahutiak interprets the semantics of this number referring to folkloric and mythological sources, actualizing a cosmogonic component in it (four corners between four walls are associated with four parts of the world) and the Christian symbolism (the children's mother was born on the fourth of August, when a wooden cross was mounted near the church). An autobiographical marker can be identified when the writer mentions about three daughters, and the narrator of the novella was the youngest child of them. H. Pahutiak focuses on the ominous mythosemantics of the number "two", related to twoness: "double objects, according to traditional beliefs, could bring misfortune" ${ }^{\text {" }}$. Thus, the narrator of the novel makes a conclusion: "The number "two" is the worst one", because according to my grandfather's belief, "two male persons cannot live together" 8 in their house. The number "one" which has the semantics of the sacred center in mythology, in H. Pahutiak's interpretation it is associated with loneliness, felt by people before death. The writer actualizes this semantics in her essay "The Gloves Wet with Dew": "Everyone dies alone, even when they are embraced by their relatives" ${ }^{\text {. }}$. In this novella there is a symbolic image of the

${ }^{3}$ Пагутяк Г. Брама для солі й вітру. Потонулі в снігах: новели, оповідання та есеї. Львів : ЛА «Піраміда», 2010. С. 147.

${ }^{4}$ Пагутяк Г. Кров і піт вигаданого світу : новели та оповідання. Потонулі в снігах: новели, оповідання та есеї. Львів : ЛА «Піраміда», 2010. С. 52.

${ }^{5}$ Жайворонок В. Знаки української етнокультури : словник-довідник. Київ : Довіра, 2006. C. 492.

${ }^{6}$ Пагутяк Г. Кров і піт вигаданого світу: новели та оповідання. Потонулі в снігах: новели, оповідання та есеї. С. 52.

${ }^{7}$ Жайворонок В. Знаки української етнокультури : словник-довідник. С. 167.

${ }^{8}$ Пагутяк Г. Кров і піт вигаданого світу: новели та оповідання. Потонулі в снігах: новели, оповідання та есеї. С. 52.

${ }^{9}$ Пагутяк Г. Рукави, вологі від роси. Мій Близький $і$ Далекий Схід : повість та есеї. Львів : ЛА «Піраміда», 2014. С. 117. 
clock of life, when it stops "the law of dead numbers comes into effect: three, nine and forty" ${ }^{10}$. The semantics of these numbers correlates with death in the Christian tradition.

In the story "Crying of the Bystrytsia River" the main character is a personified aquatic image, endowed with the functions of a narrator. The river's reflections articulate the opposition of the eternal and the transient: a long life of a water body is opposed to "a human's short miserable existence"11. The mythologem of water manifests ambivalent symbolism, related to life and death. On the one hand, the semantics of the primordial element connected to creation myths is accentuated in it: "water itself is eternal, because it is not enchained by shores and it can percolate everywhere. Shapeless substances have no time. $<\ldots>$ The Creator generates from it a multitude of mortal forms, doomed to struggle and suffer" ${ }^{\prime 2}$. On the other hand, the infernal semantics of this mythologem is outlined: "We, rivers, obediently descend to the country of death. Sand and desert are left over us" ${ }^{\prime 3}$. The semantics of destruction characteristic of eschatological myths is stressed: the river felt "capable of causing the second world flood" 14 . The story reflects the relicts of the pagan cult of water: "Veneration of rivers still lives in people: $<\ldots>$ they settled along the shores" ${ }^{15}$. The sacrifice of "clay circles, similar to the Sun"16 for a river actualizes the mythosemantics a holy marriage of two primordial elements. The figure of a child in the cradle, carried away by the river, is associated with Moses, who was put in a basket by his mother and taken to the Nile to be rescued. H. Pahutiak compares Memory and a water body: "It is also an ocean made of rivers, flowing underground. Stones, sand and oblivion are over them"17. Such identification is based on folkloric and mythological beliefs about rivers: "It also symbolizes the flow of time, eternity and oblivion" ${ }^{18}$.

In the focus of the story "Ham, the Son of Noah" there is a life whirlpool with its eternal return: "Someone has born a son. Someone has buried a friend in the afternoon"19. The episode depicting the funeral of a small child which for the first time appeared in the novel "The Compromise" and is explicated in the essay "The Way of Peony”, highlights the scary atmosphere of the story with a

${ }^{10}$ Пагутяк Г. Кров і піт вигаданого світу: новели та оповідання. Потонулі в снігах: новели, оповідання та есеї. С. 53.

${ }^{11}$ Ibid. C. 72.

${ }^{12}$ Ibid. C. 72.

${ }^{13}$ Ibid. C. 74.

${ }^{14}$ Ibid. C. 73.

${ }^{15}$ Ibid. C. 74.

${ }^{16}$ Ibid. C. 73.

${ }^{17}$ Ibid. C. 74.

${ }^{18}$ Войтович В. Українська міфологія. Київ : Либідь, 2002. С. 423.

${ }^{19}$ Пагутяк Г. Кров і піт вигаданого світу: новели та оповідання. Потонулі в снігах: новели, оповідання та есеї. С. 39. 
ritual detail: "A woman is going ahead of all and scattering pink petals"20. Interpreting the fundamental archaic antinomy of life and death in this way, $\mathrm{H}$. Pahutiak focuses on the semantics of absurdity. The allusive relationship of the title of the story with the biblical character "Ham, the son of Noah, the one who rescued innocent creatures from the Flood"21, underlines the motif of cursing a son by his father and also the binary opposition "sinful-righteous".

In the story "The Sign" the image of the field, where "a small stream of water spurts on the island of green grass" ${ }^{22}$, correlates with the motif of uniting with Nature, which has archaic roots. A tired woman is eager to go to the forest, the image of which in H. Pahutiak's prose has therapeutic semantics: "I would go there some time, lie down in the grass and fall asleep!..." ${ }^{23}$. In her essays the writer often accentuates the need of contact with Nature as a guarantee of harmony in the Universe: "A human and a field is a promise of harmony and Paradise” ${ }^{24}$. The woman and her child consider the appearance of three doves as a sign that everything will be fine. Such interpretation of this ornithological symbol corresponds to the semantics of the dove in the Biblical story. The allusive reference of the bird figure to the Old Testament and the Gospels is explicated in "The Book of Dreams and Awakening": "The dove, bringing an olive branch, informed that the Great Flood had ended. If a dove flies here, it will mean nearly the same. When you dream a dove, it predicts happiness. "Be harmless as doves, and wise as serpents"

In the short story "The Repudiation" $\mathrm{H}$. Pahutiak interprets the tragedy of a boiko woman and her children, resemantizing the Biblical story about Peter's denial of Jesus Christ. The woman did not show in any way that she recognized her perished sons serving in Bandera's partisan groups, and nobody of her fellow villagers did that: "There was such great fear" ${ }^{26}$. The author stresses: "God knows that fear is not a deadly sin, and He smiles sadly remembering Peter Simon and that Boiko woman" ${ }^{27}$. Analogizing the characters of the boiko woman and mythological Niobe, H. Pahutiak highlights the motif of suffering because of children's death related to archaic texts. Interpreting the motif of fear, $\mathrm{H}$. Pahutiak focuses on its human nature and shades the semantics of sinfulness, since even Jesus Christ addressed to God before his death:

${ }^{20}$ Пагутяк Г. Кров і піт вигаданого світу: новели та оповідання. Потонулі в снігах: новели, оповідання та есеї. С. 40.

${ }^{21}$ Ibid. C. 40.

${ }^{22}$ Ibid. C. 41.

${ }^{23}$ Ibid. C. 42.

${ }^{24}$ Пагутяк Г. Рукави, вологі від роси. Мій Близький і Далекий Схід : повість та есеї. Львів : ЛА «Піраміда», 2014. С. 126.

${ }^{25}$ Пагутяк Г. Книга снів і пробуджень. Захід сония в Урожі : романи, повісті, оповідання та новели. Львів : ЛА «Піраміда». С. 294.

${ }^{26}$ Пагутяк Г. Кров і піт вигаданого світу: новели та оповідання. Потонулі в снігах: новели, оповідання та есеї. С. 56.

${ }^{27}$ Ibid. 
"Why have you forsaken me?" Such interpretation of this motif is also characteristic of the author's "The Book of Dreams and Awakening".

In the story "The Blinding Light of Autumn" the motif of a person's ageing correlates with the mythosemantics of autumn associated with a late season of human life. There is an allusive reference of the characters of the old man and woman to the Book of Ecclesiastes, since both of them realize that "everything is meaningless". The correlation with the Old Testament text is highlighted with the figure of the cat Solomon, living with the old man. Like the King Solomon who doubts asking: "What do people gain from all their labors at which they toil under the sun" (Ecclesiastes, 1:3), the man ponders over absurdity of the work at which he wasted his best years: "I lived and did not have time. Only work, work and work" ${ }^{28}$. The woman also regrets about the lost hopes for happiness with her beloved man. She devoted her life to a disabled man, understanding the wisdom of Ecclesiastes' words: "Two are better than one" (Ecclesiastes, 4:9). The image of the setting Sun symbolizes the end of life.

In the story "The Mystery of the Heaven" the writer interprets the problems of loneliness, good and evil in the light of Christian figures and motifs. Antithesis of the heavenly and underground worlds arises through the opposition of the Angel figure and the image of the underground world of electric trains "inhabited by blind, indifferent and tired half-people-half-rivets of a hell machine” ${ }^{29}$. There is an echo of the Revelation of St. John the Divine in this story: "The appearance of the Angel in the underground was a caution for all of us" ${ }^{30}$. The sacred semantics of the Angel character and the light radiated by him is opposed to sinfulness and darkness of the city, "where he is considered as a madman and not as a savior" ${ }^{31}$. This center of "a featureless crowd", with no one worthy of the appearance of the Angel with "pure and clear eyes": "Who will dare to talk to him, having neither golden words nor golden heart?"32. The motif of loneliness also acquires apocalyptic arrangement through the figure of the character-narrator who "left a lonely field for a house with tightly closed windows" 33 .

In the story "The Gold Bowl" H. Pahutiak originally interprets the motif of expiating a deadly sin, realized through the figure of the woman who drowned a Turkish woman and took her bag with treasures. Since then she doomed herself to eternal torment: the dead Turkish woman appeared in her dreams and visions, the golden bowl also disturbed her and deprived of peace. The semantics of the struggle between sacred and demonic forces manifests itself in the motif of the

${ }^{28}$ Пагутяк Г. Кров і піт вигаданого світу : новели та оповідання. Потонулі в снігах: новели, оповідання та есеї. С. 78.

${ }^{29}$ Ibid. C. 32.

${ }^{30}$ Ibid.

${ }^{31}$ Ibid.

${ }^{32}$ Ibid.

${ }^{33}$ Ibid. C. 33. 
temptation by the Devil's who induced the woman to burn the church where the bowl was kept. The motif of expiating a deadly sin in H. Pahutiak's interpretation accumulates the semantics of inevitable retribution for a crime: "And I felt miserable realizing that one cannot return the things done" 34 .

\section{Motifs and figures of the world mythology in Halyna Pahutiak's short stories}

In the novella "The Loss of Memory" there is an image of another world, opposed to grey reality, which makes people so indifferent that they do not pay attention to red rain. The representative of that world is a woman in a long chemise, who takes the man "to the field of green rye through a breach in the wall" 35 . Space changes are accompanied by time changes: "There is no dirty, bearded old man. There is a boy sitting on the lot line and pouring soil from one hand into the other" ${ }^{36}$. Transformation of linear time into cyclical time characteristic of myths occurs in this way.

Gothic atmosphere of the short story "The House over the River" is generated by the image of an abandoned building, whose owner is buried nearby - "under almost invisible hillock" ${ }^{37}$. V. Voitovych stresses that "a house was a small projection of Cosmos, therefore it had a clear orientation towards four cardinal directions" 38 . Thus the image of the house in H. Pahutiak's story can be considered as a projection of a creation myth: "The windows face all the parts of the world" 39 . Such semantics of the dwelling image is highlighted by the association with the figure of the world tree: the man, who built it, "had rooted into Halychyna land" 40 . The availability of an attic in the building is associated with the plane of the sky, when combined with other parts, it reflects a trichotomous vertical of the world tree. The figures of nobody's horses, grazing near the house, accumulate demonological semantics, since they are connected to the author's mythologem of black horses, "pasturing at the cemetery supervised by three men" from the book "Urizh and its Spirits" 41 . In this story there is an image of the mirror characteristic of a gothic tradition. The girl does not see her reflection in it: "And thereafter the glass gets dark and splits because of thunder. The cracks look like a cobweb. <..> The tissue entangles her face and hands, looking like a bird's claws out of wide gloves of a black suit. The mirror falls

\footnotetext{
${ }^{34}$ Пагутяк Г. Кров і піт вигаданого світу: новели та оповідання. Потонулі в снігах: новели, оповідання та есеї. С. 58.

${ }^{35}$ Ibid. C. 44.

${ }^{36}$ Ibid. C. 44.

${ }^{37}$ Ibid. C. 47.

${ }^{38}$ Войтович В. Українська міфологія. Київ : Либідь, 2002. С. 557.

${ }^{39}$ Пагутяк Г. Кров і піт вигаданого світу: новели та оповідання. Потонулі в снігах: новели, оповідання та есеї. С. 47.

${ }^{40}$ Ibid.

${ }^{41}$ Пагутяк Г. Уріж та його духи. Львів : ЛА «Піраміда», 2012. С. 99. 
to pieces finally, one of the glass splinters remains on the floor"42. The semantics of this mythologem is connected to a parallel world, and its mystic dominant is highlighted by the image of the cracked mirror.

The title of the story "How the House was Built" directs the vector of interpretation towards creation myths, since "every dwelling is imago mundi and every construction copies cosmogony" ${ }^{43}$. In "Sentimental Journeys through Halychyna" $\mathrm{H}$. Pahutiak focuses on the features of a wooden house, embodying the connection with nature: "A wooden house lives its own life, it knows what it needs and it heals itself. It is patient and gentle with every creature, nestling in it in winter, even with the least bug and caterpillar" ${ }^{44}$. Such semantics is extrapolated to the image of the house in H. Pahutiak's story: "There is nothing better than a wooden house: warm and dry" ${ }^{45}$. In the novelette "The Notes of the White Bird" opposition of the images of "the concrete box" and the wooden house, "where there is a constant shade of the old garden" 46 actualizes the opposition "artificial-natural" characteristic of dystopias. An important element of any cosmogony is the sacred center, embodied in the image of the stove in the story. Such semantics is explained by the fact that "communication of people with the world of gods and ancestors occurred through sacrifice, preys and rituals" ${ }^{47}$ near a stove. In the book "Urizh and its Spirits" H. Pahutiak connects the semantics of the sacred center with the personified image of the house: "If a stove is taken apart, the house will be ruined, because the stove is its heart. Its warm heart" ${ }^{\prime 8}$. The woman's reluctance to leave the house after the death of her husband and two sons reflects the connection with her family, since "a house is a material and spiritual core of a family" 49 . The image of the door in this story symbolizes a boundary between the world of people and the other world: "The door opened: Yuzo came in. <..> The door creaked. Her husband entered" 50 . The dead men advised the woman not to sell the house: "It will be good if somebody lives in it, otherwise it will be pulled down and a new one will be built. Then our souls will never find peace" ${ }^{\text {51 }}$. It corresponds to folklore

${ }^{42}$ Пагутяк Г. Кров і піт вигаданого світу : новели та оповідання. Потонулі в снігах: новели, оповідання та есеї. С. 47.

43 Элиаде М. Мифы, сновидения, мистерии. URL: http://royallib.ru/book/eliade_mircha/ mifi_snovideniya_misterii.html (дата звернення: 11.07.2014).

${ }^{44}$ Пагутяк Г. Сентиментальні мандрівки Галичиною. Львів : ЛА «Піраміда», 2014. С. 19.

${ }^{45}$ Пагутяк Г. Кров і піт вигаданого світу: новели та оповідання. Потонулі в снігах: новели, оповідання та есеї. С. 50.

${ }^{46}$ Пагутяк Г. Записки Білого Пташка. Записки Білого Пташка : романи; повість. Київ : Український письменник, 1999. С. 137.

${ }^{47} 100$ найвідоміших образів української міфології / В. Завадська та ін. Київ : Орфей, 2002. С. 73.

${ }^{48}$ Пагутяк Г. Уріж та його духи. С. 95.

${ }^{49}$ Войтович В. Українська міфологія. С. 557.

${ }^{50}$ Пагутяк Г. Кров і піт вигаданого світу: новели та оповідання. Потонулі в снігах: новели, оповідання та есеї. С. 50-51.

${ }^{51}$ Ibid. C. 51. 
and mythological ideas about a house as "the place where souls of the dead dwell" ${ }^{52}$.

In the center of the story "The Bridge and the Spirits" there is an image of the wooden bridge, which was "a trap at night and fear at daylight, and it was impossible to cross it in night dreams" ${ }^{33}$. H. Pahutiak's interpretation of this image corresponds to the folklore and mythological sources in which a bridge was considered a connection between two worlds: "Now the bridge belongs to the spirits of water and earth, and it can be crossed only once" 54 . Demonological semantics is stressed in the images of the spirits: "When they need to pass to the other bank, they sit on people's shoulders and, having brought the load of evil spirits, they get weak and then die" ${ }^{55}$. In the book "Urizh and its Spirits" such sense emphasis are observable in the figures of the vampires, who "often meet people making them take these creatures to the other bank, because they could not go over the bridge" 56 . In the story "The Bridge and the Spirits" people pay with their hearts for "crossing the bridge. It is over

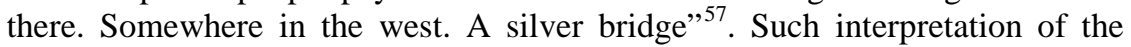
image corresponds to the opposition of the water body and the mythological river of death and the ferryman: "It is not Styx, and that spirit is not Charon"58.

In the short story "The Snowball Tree Pipe", as in "The Fairy Tale about the Snowball Tree Pipe" by Oksana Zabuzhko, H. Pahutiak resemantized the folk fairy tale of the same name, in which the motif of rivalry, dating back to the Old Testament story about Abel and Cain, is a key one. The fairy tale archetypes of a grandfather's and a grandmother's daughters are embodied in the characters of shy Olha and her envious friend Nelia from an unreliable family. The motif of rivalry evolves as Nelia's desire to humiliate Olha in the presence of the boys. In the fairy tale and in H. Pahutiak's story the forest is a place of dramatic events. Therefore, in the stories analyzed before and in "The Snowball Tree Pipe" "not a mythological motif or a plot undergo interpretation, but the modern reality and its hero are interpreted in the light of archaic myths"59.

In the story "The other" the mythological motif of turning a person into an animal is transposed into a modern context, represented by the figures of a woman and a man, that is allusively connected to the episode of Circaea's

${ }^{52}$ Войтович В. Українська міфологія. С. 557.

${ }^{53}$ Пагутяк Г. Кров і піт вигаданого світу: новели та оповідання. Потонулі в снігах: новели, оповідання та есеї. С. 54.

${ }^{54}$ Ibid.

${ }^{55}$ Ibid.

${ }^{56}$ Пагутяк Г. Уріж та його духи. С. 54.

${ }^{57}$ Пагутяк Г. Кров і піт вигаданого світу: новели та оповідання. Потонулі в снігах: новели, оповідання та есеї. С. 55.

${ }^{58}$ Ibid.

${ }^{59}$ Погребная Я. Актуальные вопросы современной мифопоэтики. URL: http://royallib.com/ book/pogrebnaya_yana/aktualnie_problemi_sovremennoy_mifopoetiki.html (дата звернення: 04.12.2014). 
turning Ulysses' shipmates into pigs. The semantics of this motif in the world mythology and the Bible correlates with sinfulness and evil forces. In H. Pahutiak's story it can be related to domination of animal features over human ones in the man character: "He is a pig with a tie, in his suit and pajamas"60. Dialectics of good and evil can be traced in the woman character: on the one hand, the God thinks that she deserves the place in Heaven living a righteous life; on the other hand - the Devil gives her a possibility to return "to the world, where chaos reigns" ${ }^{\prime}$. This demonological figure correlates with the transformed Biblical motif of temptation: the Devil suggests that the woman kill the man lest she "become a hungry restless soul after her death" ${ }^{62}$. The woman is surprised because the God does not see her otherness: "While everybody is sleeping, she breaks walls, tears off the wickerwork of electric wires, crushes doors, tears carpets to bits and pillows" ${ }^{\text {63 }}$. Reactualizing mythological motifs and figures, H. Pahutiak interprets the interaction of human and animal features in people, the fight of light and darkness.

The motif of finiteness of human life is interpreted in the short story “The Old Woman's Death": it depicts a lonely ill old woman, who refused to go to hospital, though "it was cold and extremely dirty in her house" 64 . The medical attendant persuaded the woman to cut her hair, "because she will not be admitted to hospital if she has lice" 65 . The old woman's reluctance to have her hair cut can be explained from a mythological point of view: hair was considered a place where soul dwelt and it accumulated life force ${ }^{66}$. Therefore hair cutting symbolizes the woman's death: "Her head bent from one side to the other as if she were a doll”, 67 .

In the story "The Drowned Soul", dedicated to the memory of Borys Zhdaniuk, the eschatological motif is realized through the image of a dying village, where the dead painter's mother and brother-cripple lived. Since the image of a house accumulates the semantics of ancestral memory, the house destruction symbolizes the family disappearance: "The village was vanishing in the dusk. At first the abandoned houses were drowned. Then those where there was still a fire of life. And at last the house, hiding the picture and the table at which the whole family gathered, disappeared" ${ }^{\prime 68}$. The eschatological motif in

${ }^{60}$ Пагутяк Г. Кров і піт вигаданого світу : новели та оповідання. Потонулі в снігах: новели, оповідання та есеї. С. 68.

${ }^{61}$ Ibid. C. 69.

${ }^{62}$ Ibid. C. 69.

${ }^{63}$ Ibid. C. 68-69.

${ }^{64}$ Ibid. C. 70.

${ }^{65}$ Ibid.

${ }^{66} 100$ найвідоміших образів української міфології / В. Завадська та ін. С. 413.

67 Пагутяк Г. Кров і піт вигаданого світу: новели та оповідання. Потонулі в снігах: новели, оповідання та есеї. С. 71.

${ }^{68}$ Пагутяк Г. Кров і піт вигаданого світу: новели та оповідання. Потонулі в снігах: новели, оповідання та есеї. С. 77. 
the story is highlighted by the images on the pictures of the dead artist, who painted "scared, carelessly dressed people from his native village, who were drowned in the bug in spring and autumn"69. One of the paintings reflects the semantics of the other world: "On the picture there was a man taken from the earth by the people in black suits $\langle\ldots\rangle$, and behind there was a leafless tree, as if it were a winter season" ${ }^{, 0}$.

In the story "Orpheus' Visions” the mythological motif of journey evolves through the character of the musician-flutist, who found himself in the world inhabited by animals in his vision. This motif is reminiscent of the ancient Greek myth about Orpheus. Like in the pretext, in H. Pahutiak's story music is a mediator between the worlds and is a part of the rite of passage. The opposition "cosmos-chaos" correlates with this motif: if music is capable of arranging the environment, it means that its ending leads to "an awful abyss of disharmony" ${ }^{\text {"11 }}$. The motif of music also actualizes the opposition "spiritual-material": in the flutist's vision there are "perishable bodies, which are shelters of immortal souls, temporary and unworthy. Under the impact $\langle\ldots\rangle$ of music the souls went out of those shelters and, like butterflies, fluttered around Orpheus"72. The semantics of the motif of the lost Universe harmony is articulated in the lion's words: "Carelessness is what people have been longing for, since they broke up with nature" ${ }^{73}$. In the relation to Orpheus character this motif is realized as a desire to get into the garden. Projecting the mythological motif of Orpheus' longing for his beloved Eurydice on the plane of the present time, $\mathrm{H}$. Pahutiak resemantizes it as a motif of people's longing for the lost harmony.

Antithesis of real and fictitious worlds is at the heart of the short story "Blood and Sweat of an Imaginary World", which is an intertext of H. Pahutiak's "small novel” “A Joyous Desert”. The topos of a real world, whose representative is the boy, accumulates the semantics of disharmony, a destructive impact of civilization on nature: "Old apple-trees and absolutely young trees paid their lives for the extension of the road; a huge maple without any dry branch has also been cut"74. The girl character is associated with the image of an imaginary world: the semantics of harmony with nature is realized through it. The motif of loneliness correlates with the island topos: "She lives alone, as if she were on the island"75. Since in mythology "Aa island symbolizes reliable protection from the sea of chaos" ${ }^{, 76}$, the world

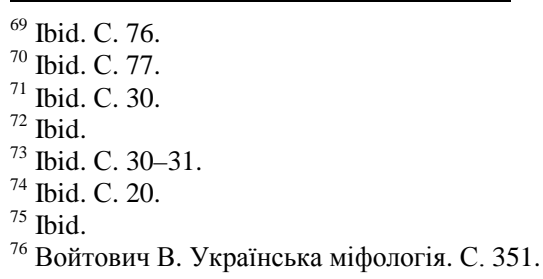


where the girl lives is associated with cosmos where "there is everything $\langle\ldots\rangle$ a forest, a river, mountains and planes" ${ }^{\text {,7 }}$. The binary opposition "death-resurrection" actualizes the motif of initiation in the story, related to the boy and the girl characters. Like in J. Fowles novelette "The Ebony Tower", in H. Pahutiak's literary work the male character is associated with a knight figure: "It as necessary to get up very early, at the sunrise, as a true knight and adventurer should do"78. The girl character in the story embodies the archetype of a Princess, who needs to be rescued from the danger threatening her" ${ }^{79}$. Deheroization of a culture hero characteristic of neomythologism is realized in H. Pahutiak's interpretation as the boy's inability to pass to the world of men as a result of initiation: the girl gets married to the other man, because her beloved one "is able to love only across the distance" ${ }^{80}$. The writer transforms the wedding motif, identified with an initiation ordeal ${ }^{81}$, highlighting the semantics of death in it: "Music has started. Out of the blue, as if it were a funeral. <..> He started dancing, and that dance was endless, like eternity, he could not look over it and see her darling in her white dress and black veil" ${ }^{82}$. Such interpretation is reminiscent of the folkloric and mythological motif of ill-fated love.

In the story "To Get into the Garden" the mythological motif of journey evolves in correlation with the main character - Hrytsko - the man with epilepsy, who plays and sings in commuter trains. Mentally he compares himself with Hryhorii Skovoroda. His friend Mykola calls Hrytsko "a holly fool”. The figure of this wandering musician is associated with God's fools, who were venerated in Christianity because of their resemblance to children. The correlation with the figure of Skovoroda is highlighted by the topos of the garden, the place where Hrytsko dreamt to get into: "He will enter the garden, lie on the entangled fragrant grass and lean against the mother-earth with his cheek" ${ }^{\text {}}$. Such interpretation actualizes the motif of longing for the lost paradise. Considering the garden a prototype of the paradise in her essay "About Flowers, Trees and Forests", H. Pahutiak explicates the semantics of this mythologem: it is "a place of friendly communication of people, plants and animals, their complete mutual understanding. The garden is an ideal that should be reached" ${ }^{84}$.

\footnotetext{
77 Пагутяк Г. Кров і піт вигаданого світу: новели та оповідання. Потонулі в снігах: новели, оповідання та есеї. С. 21.

${ }^{78}$ Ibid. C. 20.

${ }^{79}$ Ibid.

${ }^{80}$ Ibid. C. 22.

${ }^{81}$ Мелетинский Е. О литературных архетипах. Москва : Российский государственный гуманитарный университет, 1994. С. 23.

82 Пагутяк Г. Кров і піт вигаданого світу: новели та оповідання. Потонулі в снігах: новели, оповідання та есеї. С. 23.

${ }^{83}$ Ibid. C. 15.

${ }^{84}$ Пагутяк Г. Брама для солі й вітру. Потонулі в снігах: новели, оповідання та есеї. С. 93.
} 
The novella "Two Hundred Years Ago in Urizh...", opening the cycle "Seven Novellas" tells about the master-builder of the church who joked at the man on the cart, enchanting his horses. In order to disenchant them, the man was advised to "break a bottle of beer against a shaft" " is explained by H. Pahutiak in her book "Urizh and its Spirits": "his death was not an unlucky event, but it was a consequence of a counteraction of one magic to another" ${ }^{\text {"6 }}$. The writer mentions about archaic "fear of people who deal with iron - smiths and carpenters" ${ }^{87} \mathrm{~V}$. Voitovych explains the nature of this emotion with the fact that "smiths belonged to a "priest's" area since the initial "kowati" meant art on the whole and magic art in particular for the pre-Slavic world" ${ }^{88}$. Therefore the plot of $\mathrm{H}$. Pahutiak's novella is resemantization of the motif of a magic power related to the mythologem of heavenly fire.

The novella "Halia was tempted..." is allusively related to a folk song. In H. Pahutiak's literary work there is a frightful vision of fire which is burning a deer and then a woman, "tied to the pine-tree with her hair" for committing a sin: "She threw her baby into water, because she did not know, who was its father, but she knew, that it was dead and covered with hair like an animal” ${ }^{\prime 2}$. The figure of the woman who left the maternity home without her child and wanted to reduce her spiritual sufferings with a physical pain, thrusting her hand into the fire, correlates with the motif of atoning for sins in the fire of Hell.

In the novella "The Lady with Yellow Hair" the motif of a wild wedding evolves as a vision of a wedding train with a bride - "the lady with yellow streaming hair dressed in ancient clothing" ${ }^{\text {"90 }}$. The mythologem of fire correlates with this motif: "The fire followed the wedding as if it had legs" ${ }^{91}$. Like in the writer's essay of the same name from the book "Urizh and its Spirits", in her novella "The Lady with Yellow Hair" H. Pahutiak connects the autobiographical material and the mythopoetics of her prose, stressing the red color of her hair: "Nobody in my family has had such hair. It appeared from my grandfather's memory about the young bride whose ghost rushed over a night fire, whose restless soul is probably living in my body and straining to search for a shelter at night" ${ }^{\prime 2}$. Thus, the figure of a mysterious lady whose semantics is most vividly articulated in the fairy novel "The Enchanted Musicians" can be considered not only as the motif related to the Celtic mythology, but also as the one autobiographically marked.

${ }^{85}$ Пагутяк Г. Кров і піт вигаданого світу: новели та оповідання. Потонулі в снігах: новели, оповідання та есеї. С. 57.

${ }^{86}$ Пагутяк Г. Уріж та його духи. С. 35.

${ }^{87}$ Ibid.

${ }^{88}$ Войтович В. Українська міфологія. С. 231.

${ }^{89}$ Пагутяк Г. Кров і піт вигаданого світу: новели та оповідання. Потонулі в снігах: новели, оповідання та есеї. С. 58.

${ }^{90}$ Ibid. C. 59.

${ }^{91}$ Ibid.

${ }^{92}$ Ibid. 
In the novella "The World of Barbarians" there is an image of inhuman society, left by an old man and a young boy. The image of the forest where they found a shelter accumulates the semantics related to "the symbolism of the female principle or the Great Mother" ${ }^{93}$ : in winter the runaways hid themselves deep in the leaves, "pressing their knees against their breasts, like babies in a mother's womb"94. Feeling that there is no place for them in the barbarian world, the man and the boy decided to live in the forest. The semantics of the motif of searching for the lost paradise is realized as a reunion with nature: at night they dreamt "the things that trees had in their dreams: the songs of birds returning home in spring"95.

In the novella "The Others" $\mathrm{H}$. Pahutiak depicts the representatives of "a parallel world" and the man who had contacts with them. The figures of "the others" acquire demonological semantics: "They were inferior creatures: either angry, or spoilt, or destructed. $<\ldots>$ their bodies did not radiate warmth and did not have shadows" 96 . Portraying psychosomatic effects of meetings with "the others", H. Pahutiak concentratese gothic atmosphere of the literary work: "Cold sweat appeared on his forehead and his heart started beating extremely loudly" ${ }^{97}$. The image of the river accumulates the semantics of a border between the worlds: "The man could not cross the water, because it was autumn, though it was more silent on the other bank $<\ldots>$. He felt that there is no access for him to that wonderful world, that he stays with "the others" ${ }^{98}$. The topos of "the wonderful world" on the other bank is explicated by the writer in her essay "Over the Danube": it is a country, "where there is neither sorrow, nor grief, where those aspiring to be free and nearer to heaven live" 99 .

The cronotope of the novella "It will Never be in this Way" is related to the autobiographically marked toponym - the village Zalokot, whose image is mythologized: "There is a huge mountain with the sun hanging over it at noon, and it rises behind the smaller mountain, and it sets behind our house" ${ }^{100}$. The image of the plane actualizes the motif of flying, whose mythosemantics is connected to spirit rising: "Oh, if only that plane were so big that it could contain all the people from Zalokot, their dogs, cats, cows, goats and horses so that they could see their village and their mountains as birds can see at least once in their life!" ${ }^{101}$. Therefore, the image of the plane in a neo-mythological aspect manifests the semantics of a mediator between two worlds.

${ }^{93}$ Cirlot J. E. A Dictionary of Symbols. London : Routledge, 2001. P. 112.

94 Пагутяк Г. Кров і піт вигаданого світу: новели та оповідання. Потонулі в снігах: новели, оповідання та есеї. С. 59.

${ }^{95}$ Ibid. C. 60.

${ }^{96}$ Ibid. C. 61.

${ }^{97}$ Ibid. C. 60.

${ }^{98}$ Ibid. C. 61.

${ }^{99}$ Пагутяк Г. Уріж та його духи. С. 56.

100 Пагутяк Г. Кров і піт вигаданого світу: новели та оповідання. Потонулі в сніzах: новели, оповідання та есеї. С. 61.

${ }^{101}$ Ibid. C. 62. 


\section{CONCLUSIONS}

Though novels and novelettes dominate among Halyna Pahutiak's literary works, the concentration of mythopoetic characteristics in her novellas and short stories is as high as mythological intertexts are distinct in her long prose. Mythocentric character of the writer's fiction manifests itself in the titles of her short stories and novellas which indicate the vector of literary analysis, making researchers use archaic codes to interpret them. Biblical intertexts, motifs and figures of the world mythology are vivid in the author's short prose. In H. Pahutik's short stories and novellas the attributes of neo-mythologism can be traced in reactualization and resemantization of archaic senses of mythological motifs and figures aimed at interpreting the phenomena important for the author in the context of eternity. The mythologems of the garden, the sun and the river organizing space and time relations in the writer's works acquire the status of recurring ones, making it possible to go beyond the limits of the actual chronotope and return to mythical precedents. In H. Pahutiak's short prose the modern content reflects the construction of the literary world by the key principles of mythological thinking, based on binary oppositions. The nameless heroes of the writer's neo-myths can be considered as the accentuation of the relation to pre-personal archetypes.

\section{SUMMARY}

The study examines the specific features of the interpretation of mythological motifs and figures in H. Pahutiak's short prose. It looks at the resemantization of both Biblical texts and the plots of the world mythology in the writer's stories and novellas. The research made it possible to find out that in H. Pahutik's works the attributes of neo-mythologism can be traced in reactualization of archaic senses of mythological motifs and figures aimed at interpreting the phenomena important for the author in the context of eternity. In her short prose the modern content reflects the construction of the literary world by the key principles of mythological thinking, based on binary oppositions. The recurring motifs and figures made it possible to go beyond the limits of the actual chronotope and return to mythical precedents. The nameless heroes of the writer's neo-myths can be considered as the accentuation of the relation to pre-personal archetypes. These findings can be useful for further research on similar topics, in particular, on the interpretation of mythological texts in contemporary fiction.

\section{REFERENCES}

1. Войтович В. Українська міфологія. Київ : Либідь, 2002. 664 с.

2. Жайворонок В. Знаки української етнокультури: словникдовідник. Київ : Довіра, 2006. 703 с.

3. Літературознавча енциклопедія: у 2 т. Київ : ВЦ «Академія», 2007. T. $1.608 \mathrm{c}$. 
4. Мелетинский Е. О литературных архетипах. Москва : Российский государственный гуманитарный университет, 1994. 136 с.

5. Пагутяк Г. Брама для солі й вітру. Потонулі в снігах : новели, оповідання та есеї. Львів : ЛА «Піраміда», 2010. С. 87-183.

6. Пагутяк Г. Записки Білого Пташка. Записки Білого Пташка: романи; повість. Київ : Український письменник, 1999. С. 115-150.

7. Пагутяк Г. Книга снів і пробуджень. Захід сония в Урожі : романи, повісті, оповідання та новели. Львів : ЛА «Піраміда». С. 235-298.

8. Пагутяк Г. Кров і піт вигаданого світу: новели та оповідання. Потонулі в снігах : новели, оповідання та есеї. Львів : ЛА «Піраміда», 2010. C. 13-86.

9. Пагутяк Г. Рукави, вологі від роси. Мій Близький і Далекий Схід : повість та есеї. Львів : ЛА «Піраміда», 2014. С. 86-131.

10.Пагутяк Г. Сентиментальні мандрівки Галичиною. Львів : ЛА «Піраміда», 2014. 192 с.

11.Пагутяк Г. Уріж та його духи. Львів : ЛА «Піраміда», 2012. 120 с.

12.Погребная Я. Актуальные вопросы современной мифопоэтики. URL: http://royallib.com/book/pogrebnaya_yana/aktualnie_problemi_sovremennoy_ mifopoetiki.html (дата звернення: 04.12.2014).

13.Хвіртка в сад Галини Пагутяк: інтерв'ю 3 Г. Вдовиченко. URL: http://archieve/wz/lviv/ua/articles/pg/249_(дата звернення: 11.07.2014).

14.Элиаде М. Мифы, сновидения, мистерии. URL: http://royallib.ru/ book/eliade_mircha/mifi_snovideniya_misterii.html (дата звернення: 11.07.2014).

15.100 найвідоміших образів української міфології / В. Завадська та ін. Київ : Орфей, 2002. 448 с.

16.Cirlot J. E. A Dictionary of Symbols. London : Routledge, 2001. 507 p.

Information about the author:

Bokshan H. I.

Candidate of Philological Sciences, Associate Professor at the Department of Foreign Languages of the Kherson State Agrarian University 23, Stritenska str., Kherson, 73009, Ukraine 